\title{
Drinking Water as a Risk Factor to Poultry Health
}

Author(s)

Amaral LA do

Departamento de Medicina Veterinária Preventiva e Reprodução Animal - FCAV/Unesp

Mail Address

Luiz Augusto do Amaral

Faculdade de Ciências Agrárias e Veterinárias Unesp - Campus de Jaboticabal

Via de Acesso Prof. Paulo Donato Castellane $\mathrm{s} / \mathrm{n}$

14.884-900 - Jaboticabal, SP, Brazil

E-mail: lamaral@fcav.unesp.br

\section{Keywords}

microbiological quality, poultry industry, water.

\section{ABSTRACT}

In the poultry industry, the use of water with adequate physical, chemical and microbiological quality it is of fundamental importance. Since many birds have access to the same water source, quality problems will affect a great number of animals. The drinking water plays an important role in the transmission of some bacterial, viral and protozoan diseases that are among the most common poultry diseases. Important factors to prevent waterborne diseases in broiler production are the protection of supply sources, water disinfection and the quality control of microbiological, chemical and physical characteristics. Water is an essential nutrient for birds and therefore quality preservation is fundamental for good herd performance. The farmer may prevent many diseases in bird flocks by controlling the quality of the ingested water, will certainly result in decreased costs and increased profit, two essential aims of animal production nowadays.

\section{DRINKING WATER AS A RISK FACTOR TO POULTRY HEALTH}

\section{Water as a vehicle of infection for poultry}

Water is the most abundant and widely distributed chemical compound in the world. In the natural state, water is one of the purest compounds known; nevertheless, it is currently difficult to find a freshwater source that has not been altered by man. This fact is related to characteristics of countries in development, such as Brazil, where wastewaters from agriculture and urban areas, which might contain high levels of pathogenic microorganisms, are disposed of on the soil or into aquatic environment. The residues are then carried to the superficial and underground waters by the rain.

The use of consumption water with high physical, chemical and microbiological qualities is of fundamental importance in animal production because many animals have access to the same water source and a problem in the water quality would affect a great number of animals.

This is particularly relevant in poultry production, where one single water source serves thousands of animals. Therefore, control measures must be considered as priority, in order to prevent the occurrence of diseases that are spread through water, and would certainly result in great economical losses. Although water does not provide ideal conditions for pathogenic microorganism to multiply, they will generally survive for enough time to allow waterborne transmission.

Water is, therefore, an excellent transmission route of agents responsible for human and animal diseases, mainly those in which fecaloral transmission occurs, since contamination of water supplies is still gradually increasing as a result of urban and rural activities. Preventive measures and also solutions to problems that already exist must be the aim of every person. 
The scenario is not so different in the rural area, where many factors increase the risk of occurrence of waterborne diseases. Examples of such factors are the inadequate disposal of organic and inorganic residues from agriculture and livestock productions; the lack of concern regarding the quality control of the drinking water given to animals, resulting in the animals drinking water of very low quality; and finally the general belief that any water sources in the rural area have good quality and can be used as drinking water for both humans and animals, no matter if they have been submitted to adequate water treatment or not.

The use of potable water in animal rearing is a preventive approach that is expected from farmers, mainly from poultry farmers, who are unique in many aspects in Brazil. The intensive methods of rearing poultry have as consequence the more preventive consciousness regarding diseases. Disease dissemination through water can result in great losses to the producer, besides the hazards of carrying zoonosis pathogens to the herd, which would reflect in a Public Health problem.

Diseases that can be transmitted to the bird flock though the drinking water may originate from water contamination by feces and secretions of sick birds, or by the utilization of water already contaminated by pathogenic organisms that originate from other animal species and the man, such as in the case of salmonella and Escherichia coli, respectively.

Diseases caused by bacteria, virus and protozoa are among the most common diseases in the poultry industry in which drinking water plays an important role (Gama, 1995).

\section{POULTRY DISEASES POTENTIALLY TRANSMITTED BY WATER}

\section{Bacterial Diseases}

\section{Chronic Respiratory Disease (CRD)}

Etiologic Agent: Mycoplasma gallisepticum. The disease might be complicated by the presence of Escherichia coli.

Main clinical signs: respiratory distress, weight loss, respiratory rales, decreased egg production, poor flock uniformity and feed conversion, increased carcass condemnation.

The etiological agent may contaminate water by the expectorations of the birds and Escherichia colimay be present by fecal contamination of the drinking water.

\section{Colibacillosis}

Etiological Agent: Escherichia coli.

Main signs:

exacerbation of respiratory symptoms, which are complicated by septicemia, occurring after stressing situations.

The pathogen may be present due to fecal pollution of the water.

\section{Avian Cholera}

Etiological agent: Pasteurella multocida.

Main signs: appetite loss, prostration, decreased egg production, cyanotic combs, high mortality, and respiratory signs.

The pathogen may be present as a result from fecal pollution of the water.

\section{Fowl Typhoid}

Etiological agent: Salmonella Gallinarum.

Main signs: prostration, green diarrhea, mortality, and decreased production.

The agent may be present in the water as a result of fecal contamination.

\section{Diseases caused by virus Newcastle Disease}

Etiological agent: Paramyxovirus.

Main signs: respiratory, neural or digestive signs, decreased egg production, high mortality.

The etiological agent may be present in the water due to pollution by feces and discharges from the respiratory tract of infected birds.

\section{Infectious bronchitis}

Etiological agent: Coronavirus.

Main signs: respiratory impairment, decreased egg production.

The etiological agent may contaminate water by fecal pollution or by discharges from the respiratory tract of infected birds.

\section{Marek's disease}

Etiological agent: Herpesvirus.

Main signs: weight loss, paralysis, and mortality.

The etiological agent may be present in the water due to epithelial desquamation of infected birds. 


\section{Avian encephalomyelitis}

Etiological agent: Picornavirus.

Main signs: ataxia, tremor of head, neck, and limbs.

The agent may be present in water due to fecal contamination.

\section{Gumboro disease}

Etiological agent: Birnavirus.

Main signs: paleness, prostration, and low resistance.

The etiological agent may be present in water due to fecal contamination.

\section{Protozoan Diseases Histomoniasis}

Etiological agent: Histomonas meleagradis.

Main signs:

prostration, ruffled feathers, and yellowish diarrhea.

The etiological agent may be present in the water by fecal pollution.

\section{Coccidiosis}

\section{Etiological agent: Eimeria sp.}

Main signs:

dark feces with blood, drooping wings, ruffled feathers, loss of pigmentation in the shanks and combs, and flock yield lower than expected.

The etiological agent may be present in the water by fecal pollution.

\section{WATER SOURCES THAT MAY BE USED IN THE RURAL AREA}

Different water sources may be used in the rural area for animal consumption, such as springs, shallow wells, deep and artesian wells, lakes and creeks. From a microbiological point of view, the sources of superficial water are more subjected to contamination than the underground waters, although the latter are also susceptible to this type of contamination. The most common underground waters used in the rural area are:

Springs: Places where water comes up through the ground or rock and flows naturally to the ground surface or to water masses.

Shallow wells: Vertical hole manually dug in the ground and used to withdraw water. The diameter is from 1 to 5 meters and the depth varies from 3 to 12 meters.

Deep wells: well in an unconfined aquifer, drilled using machines and generally tubular.

Artesian wells: confined aquifers that sometimes contain water with pressure enough to bring it to the soil surface. They are more protected because there are layers of impermeable material below and above them and because they are more profound than the other water sources already mentioned.

It is generally believed in the rural area that the water originated from underground water sources, represented by wells and springs, is of good quality. The water is most times considered as of better quality than the treated water that is supplied in the urban areas. Although this sometimes might be the case, the current reality of environment pollution is that there is an increasing deterioration of the microbiological quality of the consumption water

In the rural area, the quality of water sources for consumption is generally compromised due to inadequate disposal of animal excreta and dead carcasses, and because septic tanks used for human dejects as well as swine and bovine barns and other installations that produce fecal pollution are incorrectly positioned in relation to the water source.

Water sources and supply used in milk production in rural areas were assessed by Amaral et al. (1995), who showed that $90 \%$ of the water samples from wells and $100 \%$ of the samples originated from springs had bacteria indicative of fecal pollution.

Microorganisms indicative of fecal pollution were present in three different types of water samples (creek, drain and artesian well), evidencing the contamination of supply sources of underground and superficial waters (Amaral et al., 1994). The study also reported that the contamination levels of the above mentioned sources were greater in the rain season. Therefore, in the periods of increased precipitation, the risk of contamination of untreated water sources used as water supply increases, which must be considered by the farmers and ratifies the need of treatment and control of water quality in the rural area.

The use of water with no microbiological quality control in livestock production poses the risk that animals are affected at any time by waterborne diseases that generally have disastrous consequences, especially in bird rearing, where many animals use one 
single water supply. It is noteworthy that the water that is given to animals is generally also used for human consumption. This represents great risk to waterborne diseases in the population that consumes the water, such as salmonellosis, colibacillosis, and parasitic diseases among others. Thus, the consumable water in the rural area must be treated and periodically analyzed for its microbiological quality; it is advisable that at least one analysis is made in both the rain and drought seasons.

\section{PROTECTION OF WATER SOURCES IN RURAL AREAS}

The following measures should be observed for the protection of water sources in the rural area, as proposed by Secretaria Especial do Meio Ambiente do Ministério do Interior (Brasil, 1988).

\section{Springs}

1. Sanitary facilities should be located downstream to the source and horizontally at least 30 meters away from any other sanitary installation.

2. There should be no rainwater or sewage waters close to the spring, such as from swine and bovine barns, septic tanks or toilets.

3. Eradicate the vegetation from the flood area of the spring, and reforest to prevent erosion.

4. Prevent disposal of solid residues in any point of the protect area of the spring.

5. Built trenches to deviate rainwater and prevent animal access to the spring area with a fence placed between 8 to 10 meters from the spring.

6. To build a collecting pipe for the spring.

\section{Shallow wells}

1. Localization upstream from potential contamination foci, at least 15 meters from dry or absorbing septic tanks and 30 meters away from swine and bovine barns.

2. The well opening must be above the ground level $(40 \mathrm{~cm})$, and there must be a sidewalk around it $(1 \mathrm{~m})$ and trenches to deviate rainwater. Alternatively, impermeable material may used to built a hummock around the well and leaning against its wall so that the water is directed outwards.

3. Walls should be made impermeable at least 3 meters from the surface, in order to prevent water to infiltrate from the surface through the lateral walls. The inside wall can also be made impermeable by a concrete tubulation.
4. The well must have a sealed cover, in order to prevent introduction of objects, dust and other potential contaminants, and the fall of animal and people inside it.

5. It should have an adequate manual or motorized means to pump water up.

6. In case the well is constructed close to river margins, it should not be located on the flood plain, so as to prevent it from being flooded.

\section{Artesian wells and deep wells}

Problems are minimized in these water sources since specialized companies and skilled technicians construct them and observe where is the ideal localization.

Although these wells are of great depth and constructed by skilled workers, they are not completely free of contamination. The presence of bacteria indicative of fecal pollution has been reported in an artesian well that was 462 meters deep (Amaral et al., 1994). This fact might be related to the presence of crevices in the rock that surround the aquifer, which many times permit infiltration of contaminants.

The farmer must be aware of such cares, especially poultry producers, who work with great numbers of animals that drink water from a single water source. These measures will greatly minimize the risk of giving water to the birds that has low hygienic-sanitary quality, which many times result in great losses due to disease dissemination, increases in production costs with the use of additional drugs besides those already used in livestock production, and eventually animal death.

The observation of the measures above mentioned would certainly minimize the risks of water source contamination. The adequate disposal of residues resulting from activities in the rural area should also be carefully observed. The absence of these caution practices compromises the quality of the drinking water used both by humans and animals, which represents a threat to the health, because the water is generally consumed without further treatment.

\section{MICROBIOLOGICAL CONTROL OF THE DRINKING WATER FOR BIRDS}

The control of the microbiological quality of the water used in the poultry industry is of fundamental importance. The knowledge of water microbiological characteristics is therefore necessary.

It should be noted that the classification of the interior waters in Brazil advises that waters up to class 
3 can be used as drinking water for animals. In other words, they should have values of total and fecal coliforms of $20,000 / 100 \mathrm{~mL}$ and $4,000 / 100 \mathrm{~mL}$, respectively. The observation of such values in the drinking water of larger animals may not result in health damage (Brasil, 1986)

Concerning poultry production, these limits may represent sanitary problems to the flock. The birds are smaller and precocious animals, and their lower resistance may cause them to be more susceptible to infections, mainly caused by pathogens of intestinal origin that might be present in water with the fecal pollution index mentioned above. Therefore, Macari (1997) and Englert (1998) recommend that waters with potability levels similar to levels applicable to humans should be also used for birds.

Corroborating these considerations, Nemedi (1984, cited by Geldreich, 1998) verified that when the levels of fecal coliforms in the water were $10^{6}, 10^{5}, 10^{4}, 10^{3}$, $10^{2}$ and 10 , the percentages of Salmonella isolation were $100 \%, 99 \%, 66 \%, 33 \%, 21 \%$ and $11 \%$, respectively.

Schwartz (1984) and Waggoner et al. (1984) (cited by Carter \& Sneed, 1996) and Reddy et al., 1995).considered that the number of microorganisms in the drinking water of birds should be $100 \mathrm{CFU} / \mathrm{mL}$ for total bacteria and $50 \mathrm{CFU} / \mathrm{mL}$ for coliforms.

The mean levels of Escherichia coli in the water of a broiler farm that used bell-type drinkers were $10^{4}$ microorganisms $/ \mathrm{mL}$ in the first week of life (Barros et al., 2001), a concerning finding since this is a high fecal contamination associated to young age of the birds. Meza (1989) states that there should be a better bacteriological control of the water provided to the birds during the initial phase, since there is a fast bacterial growth and the health risk is increased for the for birds from 1 to 21 days of age.

It must be pointed out that the water that is supplied to the birds in many farms is contaminated in the water sources. It has been reported that the samples from the water sources and reservoirs were contaminated by Escherichia coliin 10 broiler and laying hen farms, evidencing fecal pollution of the samples (Amaral et al., 1999; Amaral et al., 2001). Burcham et a/(1992) assessed water samples from 105 wells of 65 flocks in the United States and reported that fecal coliforms were present in $45 \%$ of the samples whereas Salmonella was present in $7.6 \%$, what evidences that well water may pose a risk to bird health.

Drinkers are important factors to the microbiological quality of the water provided to the birds. Open water supplies, such as troughs and bell drinkers, may present high contamination levels of $10^{7}$ and $10^{4}$ per $\mathrm{mL}$ for mesophiles and fecal coliforms (Carr et al., 1988). In the closed system (nipple), the quality of the water offered to the birds is better protected and there are no deleterious effects on bird performance compared to the open systems (Carpenter et al., 1992). Amaral et al. (1999) and Amaral et al. (2001) observed significant differences in Escherichia colinumbers when open and closed drinkers were compared in broiler and laying hen farms.

The risk of contamination with salmonellas was 6 to 7 times higher when the water given to birds was exposed to the environment (Renwick et al., 1992). Besides, more water samples were positive to salmonellas in a broiler facility when water was provided in troughs and therefore water was considered an important means of re-infection in birds (Morgan-Jones, 1980)

Salmonellas were isolated from $21.6 \%$ of the broiler farms and from $12.3 \%$ of the water samples examined in Canada by Poppe et al. (1991). The use of open drinkers in the majority of the farms was favorable to contamination and the presence of salmonellas in the litter was considered an important contamination route of the water provided to the birds.

Microorganisms from the genus Campylobacterare also important for the poultry industry and may be transmitted though water. Kapperud et al. (1993) reported a risk 3.5 higher of birds being infected by such microorganisms when the drinking water was not disinfected with chloride. Furthermore, Campylobacter jejuniwas isolated from the biofilm present in the nipple supplying pipes when the birds were infected, whereas no microorganism was isolated when the birds were not colonized (Zimmer et al., 2003).

Water supplied by closed-system drinkers improved broiler yield and reduced carcass condemnation due to colibacillosis (Silva, 1988). Besides, the use of closed drinkers improved litter quality, reduced the needed labor force and improved water quality, reducing contamination risks (Brown et al., 1995; Alfonso, 1997).

It can be thus concluded that the type of drinker is an important factor that interferes in the quality of the water that is provided to the birds.

The firs step to know the microbiological quality of the water is collecting samples to be analysed. Sampling and transportation of samples are crucial for a result that expresses the actual microbiological quality of the analyzed water. 


\section{Sampling of water for microbiological analysis}

The following guidelines have been proposed for the sampling and transportation of water samples for microbiological evaluation, based on the Order $n^{\circ} 101$ from 11/08/1993, published by Ministério da Agricultura, do Abastecimento e da Reforma Agrária (Brasil, 1993).

\section{Flasks used for sampling}

The container should be previously autoclaved at $121^{\circ} \mathrm{C}$ for 15 minutes and the volume should be 250 $\mathrm{mL}$. Alternatively, flask and lid should be boiled in clean water for 30 minutes if no autoclave is available. Care should be taken to prevent contamination of the container after boiling and autoclaving, and avoid to touch the internal side of the flask and the lid.

It is advisable hand asepsis during this procedure with alcohol $70^{\circ} \mathrm{GL}\left(740 \mathrm{~mL}\right.$ alcohol $96^{\circ} \mathrm{GL}+260 \mathrm{~mL}$ boiled water at room temperature) or washing the hands with soap and water.

\section{Procedures for water sampling}

Chloride-treated water should be collected in flasks containing $0.1 \mathrm{~mL}$ sterilized sodium thiossulphate (15\%) for each $250 \mathrm{~mL}$ of water sample. This solution may be added to the flask before autoclaving. The solution of sodium thiossulphate inactivates the residual chlorine present in the water and thus prevents the contact between the microorganisms and chlorine within the flask, which would result in false determinations that do not reflect the reality of the analyzed water source.

Hand asepsis should always be made before sampling, either using alcohol $70^{\circ} \mathrm{GL}$ or washing with soap and water.

Sampling locations may be varied. The adequate sampling method for each different location that might be present in the farms is shown bellow:

\section{Faucets localized within installations}

1. Clean the outside part of the faucet.

2. Allow water to flow for 3 to 5 minutes.

3. Close the faucet.

4. In case faucet contamination is suspected, it should be disinfected with sodium hypochloride solution containing 100 ppm of active chlorine. Dry it well to remove chlorine excess.

5. Allow water to flow for another 1 minute. In case chlorine solution was used for disinfection, decrease the water flow to a thin stream.

6. Carefully open the flask and collect as fast as possible $2 / 3$ of the total flask volume..

7. Close well and seal the lid with adhesive tape or similar.

\section{Artesian and deep wells}

The sample should be collected at the faucet that is present at the ascending pipe that comes from the well (withdrawal valve), as follows:

1. Allow water to flow for 10 minutes.

2. Collect the sample following the same guidelines described for faucet water sampling.

\section{Shallow wells}

Option 1

1. Wash a metal bucket internally and externally.

2. Flame the bucket using alcohol. Alternatively, disinfect the bucket with alcohol $70^{\circ} \mathrm{GL}$ if it is made of inflammable material.

3. Immerse the bucket inside the water, being careful not to touch the bottom or walls of the well.

4. Open the sampling flask carefully.

5. Pour the water from the bucket in the sampling flask.

6. Close well and seal.

\section{Option 2}

1. Bring the sampling flask inside the well using a thread, being careful not to touch the bottom and the walls of the well.

2. Let the flask submerge slowly into the well water.

3. Bring the flask slowly out of the well and discard the excess of sample so that the flask is $2 / 3$ full.

4. Close well and seal.

\section{Reservoirs}

1. In case the faucet at the exit of a reservoir is used, use the same procedure described for the faucet sampling.

2. Alternatively, use the flask as described for the sampling of shallow wells (option 2).

\section{Rivers, creeks and springs}

1. The flask should be submerged $(20 \mathrm{~cm})$ in such a way that the opening is directed against the stream.

2. Close well and seal.

\section{Lakes and lagoons}

1. Use the container.

2. Submerge the flask $(20 \mathrm{~cm})$, collect water sample with circular and forward movements.

3. Close well and seal. 


\section{Transportation of samples to the analysis laboratory}

Samples should be sent to the laboratory previously identified, so that collection data are not lost such as date, time and place.

The flasks should be sent preferentially under refrigeration, in boxes made of isolating material. The maximal time between sampling and analysis are as follows, for samples shipped to the laboratory in adequate conditions:

- 24 hours for treated water

- 12 hours for untreated water

- 6 hours for very polluted waters.

When it is not possible to send the samples under refrigeration, they may be sent at room temperature protected from sunlight. In such situations, the time lapsed between sampling and analysis must be lower than 2 hours.

\section{BACTERIAL ANALYSIS OF THE WATER}

Diverse microorganisms may be present in the water, both saprophytes and pathogens. In face of the potential presence of pathogenic microorganisms in the water and due to the difficulties of directly accessing these microorganisms, groups or species of microorganisms that are easily detectable and measurable may be used in the evaluation of the microbiological quality of the water. The presence of these groups of species indicates that water has been exposed to conditions that might have resulted in contamination by pathogenic species of microorganisms.

These microorganism groups or species are denominated indicators. The most used microbiological indicators in the control of the microbiological quality of the water are total and fecal coliforms. They indicate the occurrence of fecal pollution and show the risks of the presence of pathogens of intestinal origin in the water. The fact that the water is an excellent transmission means of diseases with fecal-oral infection route ratifies the importance of studies focusing these indicators in the control of the water microbiological quality.

Another group of microorganisms that are assessed in the water are the mesophile microorganisms, among which many pathogens and opportunistic pathogens are included (Lennette, 1974).

Great numbers of mesophiles in the water may interfere in the detection of coliforms, and resulting in false negative results for coliforms (Lamka et al., 1980).
Therefore, the evaluation of water microbiological quality routinely includes the assessment of total coliforms, fecal coliforms and mesophiles.

If fecal contamination of the water is detected, the poultry farmer should act fast and take all needed measures concerning water treatment, since it may act as transmission route of many diseases to the bird herd.

Care should be taken even when water is considered potable from a microbiological point of view in order to preserve this quality. Some measures should therefore be taken, among which water monitoring through periodic microbiological assessment. As already mentioned, contamination of water sources may vary throughout the year.

\section{Water treatment}

Water disinfection is the usual water treatment used in bird rearing. The aim is to eliminate pathogens that might be in the water, both those originated from contamination of the water source and those incorporated in the way between the water source and the drinkers. A second objective is to leave residual levels of chlorine in the water in order to eliminate pathogens that might be added to it if infected birds have access to water in the drinkers.

The use of water with controlled microbiological quality as drinking water for birds is of fundamental importance, considering that:

- Many birds have access to the water source;

- Birds ingest water daily;

- Water is considered a good transmission vehicle for many pathogens;

- Residues from human and animal activities pollute a great number of water sources.

To assure that the water consumed by birds will not pose risk to the flock health, it should be disinfected. The most recommended disinfecting agent is chlorine, due to its efficiency, cost, practical use and inocuity to birds when adequately applied.

Water treatment in the rural area may use diverse compounds as chlorine sources, which present different levels of available chlorine, among which two are cited below:

Calcium hypochloride - white powder that contains $70 \%$ of available chlorine

Commercial solution of sodium hypochloride clear liquid with 10-12\% available chlorine.

In emergency situations, bleach may also be used as chlorine source; it contains available chlorine levels of $2.0 \%$. 
According to Jefrey (2000), adequate chlorine dosage in drinking water for birds is $3 \mathrm{ppm}$, although birds may tolerate residual chlorine concentrations of more than $10 \mathrm{ppm}$. Concentrations of $5 \mathrm{ppm}$ are indicated to control biofilm formation. The presence of organic material rapidly inactivates chlorine, therefore, drinkers should be cleaned daily to avoid accumulation of organic material. Water $\mathrm{pH}$ should be lower than 8.5, and optimal $\mathrm{pH}$ values are from 6.0 to 8.0. Chlorination should be suspended two days before any vaccination with live bacteria and virus via drinking water. Supply of chlorinated water may be resumed 4 hours after vaccination is completed.

Residual chlorine concentrations between 2 and 5 ppm has resulted in no performance impairment and has been suggested as the levels to be added in the water supplied to broilers and laying hens (Damron \& Flunker, 1993). The microbiological quality of water given to broilers improved at $2 \mathrm{ppm}$ of residual chlorine (Valias \& Silva, 2001).

It should be remembered that chlorine reacts not only with microorganisms during chlorination, but also with organic and inorganic substances, generating the water chlorine demand (Tsai et al., 1992). The presence of residual chlorine is thus important, since it will be responsible for the elimination of the microorganisms that contaminate, by different routes, the water given to the birds. Residual chlorine should be measured 30 min after the disinfectant comes into contact with the water.

\section{SCHEME OF WATER QUALITY CONTROL IN THE POULTRY INDUSTRY THAT CAN BE ALSO BE APPLIED IN ANY LIVESTOCK PRODUCTION ACTIVITIES}

1. Chose appropriate locations for digging or drilling wells and construct them adequately;

2. Protect springs adequately;

3. Perform periodical bacteriological analysis, both in the rain and drought seasons;

4. Be familiar with the physical and chemical composition of the water in the rain and drought seasons;

5. Chlorinate the water, using the most adequate method for your property;

6. Assess levels of residual chlorine daily. The presence of residual chlorine in the water pipes at an adequate concentration (2 to $5 \mathrm{ppm}$ ) assures the absence of microorganisms pathogenic to the birds.
7. Perform annual cleaning and disinfection of water reservoirs;

8. Perform at least every six months closed system disinfection of the reservoir and the pipe systems. Ideally, such disinfection should be performed every time that a herd is marketed.

By controlling the quality of the water that is ingested by the birds, the poultry farmer will prevent the occurrence of many diseases in the flock. This will securely decrease costs and improve yield, two essential points for those currently working with animal production.

\section{REFERENCES}

Alfonso E. Automação em avicultura. In: 3 Seminário Internacional de Ciências Avícolas; 1997; Santa Cruz, Estado. País. Santa Cruz: Amevea; 1997. p.267-271

Amaral LA, Nader Filho A, Rossi Júnior OD, laria ST. Influência da precipitação pluviométrica nas características físicas, química e higienico-sanitária da água de três mananciais de abastecimento público. Revista Latinoamericana de Microbiologia 1994; 36:1-69.

Amaral LA, Nader Filho A, Rossi Júnior OD, Penha LHC. Características microbiológicas da água utilizada no processo de obtenção do leite. Pesquisa Veterinária Brasileira 1995; 15(2/ 3):85-88

Amaral LA, Rossi Junior OD, Cardoso V. Qualidade higienicosanitária da água de bebedouros pendular e nipple utilizados na criação de frangos de corte. Revista Brasileira de Ciêcia Avícola 1999; 1(2):145-148.

Amaral LA, Nader Filho A, Isa H, Barros LSS. Qualidade higiênicosanitária e demanda de cloro da água de dessedentação de galinhas de postura coletadas em bebedouros tipo nipple e taça. Revista Brasileira de Ciência Avícola 2001; 3(3):249-255.

Barros LSS, Amaral LA, Rossi Junior OD. Aspectos microbiológicos e demanda de cloro de amostras de água de dessedentação de frangos de corte coletadas em bebedouros pendulares. Revista Brasileira de Ciência Avícola 2001; 3(2):193-198.

Brasil. Ministério da Agricultura do Abastecimento e da Reforma Agrárias. Portaria n 101 de 11/8/1993. D.O.U. de 17/8/1993, Brasilia, DF.

Brasil. Conselho Nacional do Meio Ambiente. Conama. Diario Oficial da União de 30/07/1986.

Brasil. Ministério do Interior. Secretária Especial do Meio Ambiente. A água que você bebe. $2^{a}$ ed. Brasília; 1998.

Brown TM, Beck MM, Schulte DD, Jones DD, Douglas JH, Scheideler SE. Nipple waterers for chick batteries: design, efficiency and cost analysis. Poultry Science 1995; 74:457-462. 
Carpenter GHRA, Peterson WT, Jones KR, Hypes WA. Effects of two nipple drinker types with different flow rates on the productive performance of broiler chickens during summerlike conditions. Poultry Science 1992; 71:1450-1456.

Carr LE, Murphy DW, Wabeck, CJ. Livestock Environment In: III Proceedings of the International Livestock Environment Symposium; 1988. p.279-285.

Carter TA, Sneed RE. Drinking water quality for poultry. Published by: North Carolina Cooperative Extension Service; 1996. [Acessed dec. 14, 2004]. Available at: http://www.bae.ncsu.edu/programs/ extension/evans/ps\&t-42.html.

Damron BL, Flunker K. Broiler chick and laying hen tolerance to sodium hypoclorite in drinking water. Poultry Science; 1993; 72:1650-1655

Englert S. Produção de frangos de corte. In: Englert, S. Avicultura: tudo sobre raças, manejo e alimentação. $7^{\text {a }}$ ed. Guaíba: Agropecuária; 1998. p.94-151.

Gama MSQ. Água, que cura, que nutre, que mata. Aves \& Ovos 1995; p.30-33

Geldreich EE. The bacteriology of water. In: Colier L, Balaws A, Sussman M. Microbiology and microbial infections. $9^{\text {th }} \mathrm{ed}$. London: Arnold Pub; 1998.

Jefrey JS. Sanitation-Disinfection. Basics for Poultry Flocks (22/02/ 2000). Davis: University of California, Veterinary Medicine Extension. [Acessed dec. 14, 2004]. Available at: http:// www.vetmed.ucdavis. edu/vetex/Home.html.

Kapperud G, Skjerve E, Vik L, Hauge K, Lysaker A, Aalmen I, Ostroff SM, Potter M. Epidemiological investigation of risk factors for Campylobacter colonization in Norwergian broiler flocks. Epidemiology and Infection 1993; 111(2):245-255.

Lamka KG, Lechevallier MWE, Seidler RJ Bacterial contamination of drinking water supplies in a modern rural neighborhood. Applied and Environmental Microbiology 1980; 39 (4):734-38.

Lennette EH, Sapulding EH, Truant JP. Manual of clinical microbiology. $2^{\text {a }}$ ed. Washington:American Society for Microbiology; 1974.

Macari M. Qualidade da água e bebouros para frangos de corte: tipos, vantagens e desvantagens. In: Conferência Apinco'97 de Ciência e Tecnologia Avícolas, São Paulo. Brasil. Campinas: Facta; 1997. p.121-143.

Meza H. Controle de qualidade na produção de frangos de corte. Avicultura \& Suinocultura Industrial 1989; 80:38-44

Morgan-Jones SC. The occurrence of Salmonellae during the rearing of broiler birds. British Poultry Science, 1980; 21(6):463-470.

Poppe C, Irwin RJ, Messier S, Finley GG, Oggel J. The prevalence of Salmonella enteritidis and other Salmonella spp. among Canadian registered commercial chicken broiler flocks. Epidemiology and Infection 1991; 107:201-211.
Reddy MR, Raju MVLN, Chawak MM, Rama Rao SV. Importance of water in poultry health. Poultry Adviser 1995; 28(6):31-37.

Renwick AS, Irwin RJ, Clarke RC, Mcnab WB, Poppe C. Epidemiological association between characteristics of registered broiler chicken flocks in Canada and the Salmonella culture status of floor litter and drinking water. Canadian Veterinary Journal 1992; 33:449-458

Silva EN. Passo a passo contra Escherichia coli. Avicultura Industrial 1998; 88(1057):24-27.

Tsai S, Schade JE, Molyneux BT. Chlorination of poultry chiller water:chlorine demand and disinfection efficiency. Poultry Science 1992; 71(1):188-196.

Valias APGS, Silva EN. Estudo comparativo de sistemas de bebedouros na qualidade microbiológica da água consumida por frangos de corte. Revista Brasileira de Ciência Avícola 2001; 3(1): 83-89.

Zimmer M, Barnhart H, Idris U, Lee MD. Detection of Campylobacter jejuni strains in the waterlines of a commercial broiler and their relationship to the strains that colonized the chickens. Avian Diseases 2003; 47(1):101-107. 